\title{
MATRIX SUPPORT WORK: DIFFICULTIES IN THE SCOPE OF BASIC HEALTHCARE
}

Amanda de Araújo ROMERA ${ }^{\mathrm{a}}$, Anne Jaquelyne Roque BARRÊTO ${ }^{\mathrm{b}}$,Lenilde Duarte de SÁc, Sandra Aparecida de ALMEIDA ${ }^{d}$, Jordana de Almeida NOGUEIRA ${ }^{\mathrm{e}}$, Célia Maria Cartaxo Pires de SÁ ${ }^{\mathrm{f}}$

\section{ABSTRACT}

Qualitative research under the analysis of contents, thematic modality, aimed to identify the difficulties lived by the matricial supporter in its practice in the Primary Health Care. The scenery of the study were six units of family health located in one of the five Sanitary Districts of João Pessoa-PB. The data collection was performed from August to September 2010, through semi directed interviews, in which ten professionals who worked as matricial supporters participated. According to the speeches the difficulties faced relate to the ignorance of some professionals of the health team toward the function of the matricial supporter in the Basic Health Attention; lack of autonomy and administrative overload. In this sense, it is suggested that a process of reflection about the work of the matricial supporter with the health team aiming to acknowledge which contribution of this professional in the reorganization of the work of the team of basic attention.

Descriptors: Nursing. Primary health care. Health management.

\section{RESUMO}

Estudo exploratório, tendo como referência a abordagem qualitativa, que objetivou identificar as dificuldades vivenciadas pelo apoiador matricial em sua prática na Atenção Básica em Saúde. O cenário do estudo foram seis unidades de saúde da família localizadas em um dos cinco Distritos Sanitários de João Pessoa-PB. A coleta de informações foi realizada no período de agosto a setembro de 2010, por meio de entrevistas semidirigidas, de que participaram dez profissionais que atuavam como apoiadores matriciais. De acordo com as falas, as dificuldades enfrentadas relacionam-se ao desconhecimento de alguns profissionais da equipe de saúde a respeito da função de apoiador matricial na Atenção Básica em Saúde; à falta de autonomia e à sobrecarga administrativa. Nesse sentido, sugere-se que haja um processo de reflexão sobre o trabalho do apoiador matricial com a equipe de saúde, no intuito de conhecerem melhor possíveis contribuições desse profissional à reorganização do processo de trabalho da equipe de atenção básica.

Descritores: Enfermagem. Atenção primária à saúde. Gestão em saúde.

Título: Trabalho do apoiador matricial: dificuldades no âmbito da atenção básica em saúde.

\footnotetext{
a Studying a master's degree in Nursing at the UFPB. Healthcare Nurse at the Complexo Hospitalar de Mangabeira Governador Tarcísio Burity. Member of the Tuberculosis Qualification and Study Group of Paraíba. João Pessoa, Paraíba, Brazil.

b Studying a doctorate in Nursing at the Federal University of Paraíba (UFPB). Instructor at the Universidade Federal de Campina Grande and Faculdade de Enfermagem Nova Esperança. Member of the Tuberculosis Qualification and Study Group of Paraíba. João Pessoa, Paraíba, Brazil.

c Post-doctorate in Nursing from the University of São Paulo's Nursing School (EERP-USP). Associate Professor III at the UFPB. General Postgraduate Coordinator at the UFPB. João Pessoa, Paraíba, Brazil.

d Studying for a doctorate in Nursing at the UFPB. Instructor at the Faculdade de Enfermagem Nova Esperanca. Members of do HIV/AIDS, Health and Sexuality Study Center connected to the Postgraduate Nursing Program (PPGEnf) at the UFPB. João Pessoa, Paraíba, Brazil.

e Post-doctorate in Nursing from the EERP-USP. Assistant Professor IV at the UFPB. Coordinator of the PPGEnf at the UFPB. João Pessoa, Paraíba, Brazil.

f Specialist in Public Health, Preventive and Social Medicine and Public Healthcare Policy Management at the UFPB. Instructor at the Faculdade de Ciências Médicas da Paraíba. Public Servant at the Municipal Prefecture of João Pessoa.
} 


\section{RESUMEN}

Investigación cualitativa bajo el análisis de contenido, modalidad temática, objetivó identificar las dificultades vividas por el asistente matricial en su práctica en la Atención Primaria de Salud. El escenario del estudio fueron seis unidades de salud de la familia localizadas en uno de los cinco Distritos Sanitarios de João Pessoa-PB. La recopilación de informaciones fue realizada en el período de agosto a septiembre de 2010, por medio de entrevistas semidirigidas, en las que participaron diez profesionales que actuaban como asistentes matriciales. De acuerdo con las declaraciones, las dificultades enfrentadas se relacionan al desconocimiento de algunos profesionales del equipo al respecto de la función de asistente matricial en la Atención Básica; falta de autonomía y la sobrecarga administrativa. En ese sentido, se sugiere que haya un proceso de reflexión sobre el trabajo del asistente matricial con el equipo de salud con la finalidad de (re)conocer qué contribución(es) aporta ese profesional en la atención básica.

Descriptores: Enfermería. Atención primaria de salud. Gestión en salud.

Título: Trabajo del asistente matricial: dificultades en el ámbito de la atención primaria en salud.

\section{INTRODUCTION}

Primary Health Care (PHC) can be understood as the preferred entranceway for the health system and is responsible for the coordination and conduction of healthcare for the individual, family and community ${ }^{(1)}$.

In the 1990's, the concept of PHC in Brazil was expanded with the objective of improving compliance with the new health policy, with the Unified Health System (Sistema Único de Saúde - SUS), "based on the principles of universality, equity and integrality and the organizational guidelines for decentralization and social participation"(2). In this perspective, in Brazil, the term Primary Health Care (PHC) came to be used to express the expanded concept of PHC, with Family Health as the priority strategy and substitutive model for the organization of healthcare in the country ${ }^{(2,3)}$.

The primary functions of $\mathrm{PHC}$, in order to boost the operation of the system, are related to the coordination of the healthcare of users shared by various instances of the healthcare network and the capacity to select people that require access to more complex care offered at other levels in the health system $^{(4)}$. However, in Brazil these functions are still not practiced widely, considering the construction of integrality in the healthcare system in the country ${ }^{(5)}$.

The concept of integrality adopted in this study is related to the main doctrinal principle of the SUS, describe as: "the guaranteed provision of a coordinated and continuous set of preventive, curative and collective actions and services, required in each case for all levels of healthcare complexity, covering actions for the promotion, protection and recovery of health"(6).
When considering this concept, there are some problems impacting this process and intimately related to organization and managerial issues, among which we can highlight: fragmentation of health care and insufficient and inadequate clinical accountability; differentiated social/organizational valorization of professional knowledge and mutually complementary services and contractual and regulatory mechanisms that do not value the territory and co-responsibility of health services ${ }^{(5)}$.

In the perspective of facing these challenges, the Ministry of Health has proposed the Matrix Support strategy to facilitate the direction of workflows in PHC, promoting coordination between health teams and management. Matrix Support is an organizational arrangement and methodology for the management of health work, aimed at expanding possibilities of clinical implementation and dialogical integration between distinct specialties and professions. It is an instrument that proposes the reorganization of health services founded on sanitary responsibility, which uses permanent education as the guiding principle of this work ${ }^{(1,5)}$.

In this sense, the health professional, in the role of matric support worker (AM), should have both pedagogical and managerial competencies and skills that favor the construction of spaces for collective and democratic dialogs in order to initiate the reorganization of the work process and the transformation of healthcare practices based on the integrality of the service ${ }^{(5)}$.

The literature studied highlights the scarcity of research showing the difficulties in the matrix support work under the scope of PHC, and the majority of such are specific to the mental health area. 
With gradual insertion of the AM in the PHC services, there is a need to understand how this work is carried out, especially in relation to the difficulties faced in day-to-day work.

In the perspective of including the phenomenon being studied, this study aimed to identify the difficulties experienced by the matrix support worker in their PHC practice.

This article is an excerpt from the dissertation entitled "Matric Support" realized in Family Health teams ${ }^{(7)}$.

\section{METHODOLOGY}

This is an exploratory study, using a qualitative approach as a basis. The research was carried out at six Family Health Units (USF) located at one of the five Health Districts (DS) in João Pessoa/ $\mathrm{PB}$. The choice of DS was made based on it being one of the most populous in the municipality, with 53 Family Health teams and 37 USFs. It is worth noting that six of these are Integrated Units (UI), i.e. compound services, with four health teams each. Each UI is accompanied, on average, by two AMs, totaling 12 professionals in these services. The choice of these UIs represented almost $50 \%$ of the family health teams in this district.

The following criteria were adopted to define the sample in the study: working as an AM at the integrated family health unit and holding this position at the same unit for a minimum of six months. There were no exclusion criteria, however, all of the $12 \mathrm{AMs}$ at the UIs were included. The finalization of the collection of data was also guide by the sample saturation technique frequently used in qualitative research investigations ${ }^{(8)}$. In this perspective, the evidence from the $10 \mathrm{AMs}$ made up the empirical material of the study, and included 2 nurses, 4 physiotherapists, 2 pharmacists, 1 psychologist and 1 nutritionist.

The collection of information was realized in the period from August to September 2010 using semi-structured interviews. The interviews were conducted using a semi-structure script with six questions inherent in the support work and difficulties encountered. The collection of data was only realized after signing the Declaration of Free and Clarified Consent. All of the interviews were held in the meeting room at the health units by the investigator responsible for the study.
The audio from the interviews was recorded with the intention of facilitating and obtaining the most detailed empirical material possible, and then fully transcribed in the month of October 2010.

The participants were codified using the acronym AM (matrix support worker) and Arabic numerals according to the sequence of the interviews, in order to guarantee anonymity and comply with the requirements of National Health Council Resolution 196/96 which covers the regulatory standards and guidelines for research involving humans.

The empirical material was analyzed using the thematic Content Analysis. This consists of a sequence composed of three basic steps for organizing and exploring the information from the interviews: fluctuation reading (pre-analysis), exploration of the material and/or codification, and treatment of the result - inference and interpretation $^{(9)}$.

In the pre-analysis phase for constitution of the corpus, ten of the interviews conducted were selected, moving onto the phases for exploration of the material and treatment of the results obtained and interpretation, with all of the content of the recordings analyzed, followed by transcription of the material recorded for each participant. Once transcribed, the homogeneity, representativeness and pertinence of the information was noted.

After the pre-analysis phase, the longitudinal and transverse fluctuation modes were completed. Codification then began based on the registration units and formulation of pre-hypotheses.

The registration units were highlighted in order to reach the proposed objective through prior analysis of the content of the interviews. In turn, the registration units formed the following units of meaning: lack of understanding among professionals from the ESF in relation to $\mathrm{PHC}$ and the idea of the AM, and Difficulties in the work of the AM: lack of professional autonomy/governability and administrative overloading.

Subsequently, the units of meaning identified in the interviews with convergent, divergent and repeated content were considered. Thus, excerpts were made from the interviews corresponding to each unit of meaning. This confirmation enables a central thematic element to be confirmed: Matrix supporter work: difficulties within the scope of Basic Health Care. 
The project that gave rise to the study was approved by the Research Ethics Committee at Faculdade de Enfermagem Nova Esperança (FACENE) under registration number 136/2010 and CAEE $n^{\circ}: 3574.0 .000 .351-10$.

\section{RESULTS AND DISCUSSION}

In sequence, two subcategories arose that delimitated the Matrix supporter work: difficulties within the scope of Basic Health Care category.

\section{Lack of understanding among professionals from the ESF in relation to $\mathrm{PHC}$ and the idea of the AM}

One of the difficulties identified in the interviews with matrix support workers is the issue of a lack of commitment and noncompliance by professionals in the health team in reorganizing the work process at the health unit in order to achieve results in the healthcare of the local population.

Another issue is compliance by the professional, [...]
sometimes the professional does not collaborate. It is
very difficult for use to change people's minds, we can't
do it. (AM7)

[...] the issue of commitment above all because, unfortunately, not everyone has the same objective, or the same commitment [...]. (AM5)

Another issue that makes things very difficult is commitment by some of the workers... there are those that are not committed to the work [...]. (AM6)

We can highlight that historically in health institutions, the organization, governance style and power structure conditioned and determined the behavior and posture of health services that were not very favorable to the production of humanized care. This power system, based on the Taylorism, causes lack of commitment and alienation among the majority of workers. In this perspective, a work process centered on procedures, a reality still faced currently, and not the production of health, tends to dilute the involvement of health teams with users ${ }^{(5)}$.

Thus, the AM constitutes a management strategy with the intention of initiating review processes and remodeling of health practices in order to strengthen the ideals of Brazilian Health
Reform through reorganization of the basic health care process for the establishment of a connection, reception and accountability for caring for others.

There are some organizational concepts and arrangements that enable - but do not guarantee - the joint responsibility of the health worker in the reformulation of the production of care. According to this perspective, the planning, evaluation and possible contracts for targets should be implemented in a participative manner and with institutional matrix support ${ }^{(10)}$.

Another difficult identified in the AM interviews relates to lack of understanding about the function of the support in the health unit. According to the subjects in this study, health professionals understand that the AM is the manager of the unit (coordinator, director), i.e. a figure of power (inspector), as below:

Look, my greatest difficulty or weakness that I perceive is the view that some professionals have of the support worker, [...] such as the director of the unit, the figure that has the power [...]. (AM3)

The issue is that they (health professionals) view support professionals as an inspector [....]. (AM2)

[...] we are viewed like a manager, like a person that governs, so this impedes the relationship with workers, professionals and the community $[\ldots .$.$] . (AMI)$

It is worth remembering that the inclusion of a new worker at the health unit tends to cause a certain lack of trust and/or rejection by workers already working at the health unit. The challenges is to get past this barrier and initiate local communicative actions for building a relationship between the AM and basic health care professionals. These professionals do not only report to the governing body, but perform team activities, helping in the management and organization of work processes ${ }^{(5)}$.

Therefore, the AM carries out the functions of aiding teams, the management and organization of work processes, working with teams dialogically, helping to build collective spaces where the group can analyze, define tasks and elaborate intervention projects. Given that the strategy of the AM is aimed at building an democratic organizational culture in the managerial field, and the conduction of knowledge valuing the uniqueness of all cases, at an epistemological level, the strategy tends to favor 
an interactive balanced between the knowledge of various professionals in the team ${ }^{(5)}$.

Unlike the healthcare management methodology proposed by the AM, the traditional managerial logic does not offer space for reflection and the shared construction of interventions, building a vertical power hierarchy, acting a probable for lack of understanding about the support function, alongside the managerial model's resistance to accepting change.

It is worth reiterating that the change process generates conflicts within relationships and, in this case, the position of AM has brought uncertainty for professionals in the health team, perhaps because of fear of the new or being out of their comfort zone for possible changes that could occur in the service. Thus, this fragility when facing change often results from the fact that old guidelines, although inadequate, assure a model of common conduct and representations in respect to the technician's place in the professional relationship ${ }^{(11)}$.

Lastly, reorganization of the work process through professional collaboration, presupposed in the work of the AM, where there are professionals with distinct specialties trained in the traditional management model, may lead workers to protect themselves in various manners, including standards, protocols and other methods of establishing roles ${ }^{(12)}$.

To aid the understanding of PHC professionals in relation to the role of the AM as well as reformulation of health professional practice in their respective teams, which is an essential condition for achieving integrality, Permanent Health Education may be used as a strategy to stimulate spaces for exchanging experience and knowledge with other health professionals, thereby clarifying doubts in relation to their position in the health team.

Difficulties in the work of the AM: lack of professional autonomy/governability and administrative overloading.

According to reports, administrative duties demand the majority of the time worked by matrix support workers and interfere in the development of their specific activity, described as one of the barriers in their work process.

[...] so we have bureaucratic demands that create a certain barrier in the support work, I often spend one month without being $\{$ professional category $X\}[\ldots .$.$] . So,$ sometimes the support worker has a lot of bureaucratic demands meaning we can't do other things. In fact, we often focus on people management, and clinical work takes second place. (AM8)

The greatest difficult that we face as support workers is exercise my professional, because there are so many bureaucratic issues and management issues that sometimes people confuse our role [...]. (AM9)

When emphasizing the lack of room to carry out the work relating to their professional training for clinical care, this presupposes that there is a misunderstanding about the work of the AM by both health professionals from the ESF as well as the professional working with the support material.

We can highlight the Family Health Support Center (NASF) as a recent proposal by the Ministry of Health - GM Ordinance $n^{\circ} 154$, January $24^{\text {th }} 2008$ - established in the operational area of the AM. According to this ordinance, the NASF team should be constituted by different health professionals, an interdisciplinary work that has the main function of support of the SF team, so that it can increase resoluteness and, although they may undertake individual care, this activity is not seen as a priority ${ }^{(5,13)}$.

The AM works in the healthcare management, the purpose of which is to expand the clinic and increase the resoluteness of health actions through the integrated work of PHC team professionals. Specifically, the support worker role together with PHC teams is to aid in the management - managerial, policy, pedagogical, and treatment - and organization of work process, with the construction of collective discussions spaces where the group will evaluate, define and elaborate treatment projects ${ }^{(19)}$.

These professionals should share the longitudinal monitoring of the clientele connected to the Health Unit, boosting the Healthcare Network with the coordination of actions by the PHC team and other services $^{(5)}$. So, even if involved in healthcare, by aggregating knowledge and contributing to shared interventions, the responsibility for conducting cases lies with the ABS team.

Lack of understanding about the work of the AM may be occurring owing to these professionals taking on problems from other members of the primary healthcare team and complying with institutional expectations to the detriment of 
implementing the objectives of their own service. As previously discussed, the role of support workers is not very clear, as well as the definition of the tasks and criteria for using an AM for the shared construction of clinical and health guidelines to be agreed by the manager, NASF team and primary healthcare team ${ }^{(13,14)}$.

Furthermore, some structural problems, such as the scarcity of specialized primary healthcare services, may lead to use of professionals working with $\mathrm{AM}$ in a substitutive manner, diminishing the service and impeding understanding about their $\operatorname{position}^{(5)}$.

Another aspect pointed out as being an impediment in the work of the AM was the lack of professional autonomy and/or governability for resolving some impasses and demands, both in relation to users and structural issues, as well as the primary care team. This issue mainly relates to standardization of public management.

There are some problems such as guaranteeing certain things, in order to be able to work [...]. (AM1O)

[...] administrative issues [...] there has been no nebulizer at the Unit for about a year, [...], we call the bidding sector to find out about the procurement process, and sometimes there are barriers in the public service that affect our support work [...]. (AMs)

[...] we have certain difficulties in solving structure problems, the physical structure of the unit, which are important, but outside of our governability[...]. (AM3)

According to Situational Strategic Planning, governability relates to an actor's level of control over variables involved in organizational processes and their results ${ }^{(15)}$ and is the central point in the field involving planning and management.

A multitude of actors is therefore recognized, with different levels of power and interests, disputing projects and the resources to implement them. Therefore, planning and management no longer relate to a problem of administration, but a problem of interaction between actors seeking their objectives ${ }^{(16)}$.

As stated, the work of PHC teams with the AM has been influenced by the biomedical model and Taylorism for the division and organization of the work, leading to its fragmentation and separation between conception and execution, which in association with managerial control of the process and the rigid hierarchy has led to demotivation and alienation of workers, as well as an imbalance in workloads. ${ }^{(17)}$.

The organization of health services according to the AM concept presupposes three guidelines: therapeutic connection, collegiate management and transdisciplinarity. In the operationalization of PHC, this means a reformulation of knowledge and practices that generate changes in the logic for operation of the health services, with new forms of operating the work process, both in relation to healthcare and the execution of managerial and administrative practices required for the operation of the unit and team work.

Collegiate management, i.e. breaking the rule of single and hierarchical verticality in organizational workflows, is expected to overcome the hegemonic managerial system. Collegiate management and permanent health education will be innovative in the current Family Health Training Centers, enabling new arrangements and new organizational structures ${ }^{(19)}$.

\section{FINAL CONSIDERATIONS}

The study showed there is a lack of understanding by health professionals in relation to the role of AM in PHC, lack of commitment and noncompliance by the Am in reorganizing local work process, in addition to diverting the support role toward administrative activities and provision of specialized services, which conflicts with the lack of autonomy and governability for carrying out actions.

In this perspective, the barriers identified in the work of the AM have a negative impact on the consolidation of a health model that presupposes the practice of integral and humanized work, permeated by the principles and guidelines that govern PHC in Brazil.

A reflection process is suggested in relation to the work of the AM and the health team, and the actual support, with the objective of recognizing and understanding the contributions of these professionals in the implementation of PHC. There is a need to carry out further research, not only in the municipality studied but also other scenarios, with the intention of recognizing and understanding the work of the AM, especially 
in relation to the work process in PHC services. Studies should also be conducted in relation to the perception of family health teams in relation to matrix support workers.

\section{REFERENCES}

1 Almeida PF, Fausto MCR, Giovanella L. Fortalecimento da atenção primária à saúde: estratégia para potencializar a coordenação dos cuidados. Rev Panam Salud Pública [Internet]. 2011 [citado $2012 \mathrm{Jul}$ 31];29(2):84-95. Available in: http://www.scielosp. org/pdf/rpsp/v29n2/a03v29n2.pdf.

2 Giovanella L, Mendonça MHM, Almeida PF, Escorel S, Senna MCM, Fausto MCR, et al. Saúde da família: limites e possibilidades para uma abordagem integral de atenção primária à saúde no Brasil. Ciênc Saúde Coletiva [Internet]. 2009 [citado 2013 Nov 27];14(3):783-94. Available in: http://www.scielo. $\mathrm{br} / \mathrm{pdf} / \mathrm{csc} / \mathrm{v} 14 \mathrm{n} 3 / 14 . \mathrm{pdf}$

3 Ministério da Saúde (BR), Secretaria de Atenção à Saúde, Departamento de Atenção Básica. Política Nacional de Atenção Básica. Brasília (DF): Ministério da Saúde; 2012.

4 Starfield B. Atenção primária: equilíbrio entre necessidades de saúde, serviços e tecnologias. Brasília (DF): Unesco; 2002.

5 Cunha GT, Campos GWS. Apoio matricial e atenção primária em saúde. Saúde Soc [Internet]. 2011 [citado 2011 Nov 14];20(4):961-70. Available in: http://www.scielo.br/scielo.php? script=sci_ arttext\&pid=So 104-1290201 1000400013\&lng=en $\& n r m=i s o$.

6 Brasil. Lei n. 8.080, de 19 de setembro de 1990: dispõe sobre as condições para a promoção, proteção e recuperação da saúde, a organização e o funcionamento dos serviços correspondentes e dá outras providências [Internet $]$. Brasília (DF); 1990 [citado 2011 Nov 14]. Available in: http://portal.saude.gov. br/portal/arquivos/pdf/lei8080.pdf.

7 Romera, AA. Apoio Matricial realizado nas equipes de Saúde da Família [monografia ]. João Pessoa (PB): Faculdade de Enfermagem Nova Esperança; 2010.

8 Fontanella BJB, Ricas J, Turato ER. Amostragem por saturação em pesquisas qualitativas em saúde: contribuições teóricas. Cad Saúde Pública [Internet]. 2008 [citado 2013 Nov 28];24(1):17-27. Available in: http://www.scielo.br/pdf/csp/v24n1/02.pdf
9 Bardin L. Análise de conteúdo. Lisboa: Edições 70; 2011.

10 Campos GWS. Cogestão e neoartesanato: elementos conceituais para repensar o trabalho em saúde combinando responsabilidade e autonomia. Ciênc Saúde Coletiva [Internet]. 2010 [citado 2010 Set 27];15(5):2337-44. Available in: http://www.scielosp. org/scielo.php?script $=$ sci_arttext\&pid $=\mathrm{S} 1413$ $-81232010000500009 \& \operatorname{lng}=$ en\&nrm $=$ iso.

11 Cambuy K. Experiências Comunitárias em Saúde Mental: repensando a clínica psicológica no SUS [tese]. Campinas (SP): Pontifícia Universidade Católica; 2010.

12 Furtado JP. Arranjos institucionais e gestão da clínica: princípios da interdisciplinaridade e interprofissionalidade. Cad Bras Saúde Mental [Internet]. 2009 [citado 2012 Jul 31];1(1):178-89. Available in: http://www.hc.ufmg.br/gids/anexos/arranjos_ institucionais_e_gestao_da_clinica_juarez_furtado. pdf.

13 Ministério da Saúde (BR), Secretaria de Atenção à Saúde, Departamento de Atenção Básica. Diretrizes do NASF: Núcleo de Apoio a Saúde da Família [Internet]. Brasília (DF); 2010 [citado 2011 Abr 24]. Available in: http://bvsms.saude.gov.br/bvs/publicacoes/caderno_atencao_basica_diretrizes_nasf.pdf.

14. Montezeli JH, Peres AM. Competência gerencial do enfermeiro: conhecimento publicado em periódicos brasileiros. Cogitare Enferm [Internet]. 2009 [citado 2010 Out 05];14(3):553-8. Available in: ojs. c3sl.ufpr.br/ojs2/index.php/cogitare/article/down$\mathrm{load} / 16189 / 10707$.

15 Kurcgant P. Gerenciamento em enfermagem. $2^{\mathrm{a}}$ ed. Rio de Janeiro: Guanabara Koogan; 2010.

16 Sá MC. Subjetividade e projetos coletivos: mal-estar e governabilidade nas organizações de saúde. Ciênc Saúde Coletiva [Internet]. 2001 [citado 2012 Mar 01]; 6(1):155-64. Available in:http://www.scielosp. org $/$ scielo.php? script $=$ sci_arttext\&pid $=$ S 1413$-81232001000100013 \& \operatorname{lng}=$ en\&nrm=iso.

17 Matos E, Pires D. Teorias administrativas e organização do trabalho: de Taylor aos dias atuais, influências no setor saúde e na enfermagem. Texto \& Contexto Enferm. 2006;15(3):508-14.

18 Ximenes Neto FRG, Sampaio JJC. Processo de ascensão ao cargo e as facilidades e dificuldades 
no gerenciamento do território na Estratégia Saúde da Família. Rev Bras Enferm [Internet]. 2008 [citado 2010 Out 06];61(1):36-45. Available in: http://www.scielo.br/scielo.php? script=sci_ arttext\&pid=So034-7 1672008000100006\&lng=e $\mathrm{n} \& \mathrm{nrm}=$ iso.
19 Ministério da Saúde (BR), Secretaria de Gestão do Trabalho e da Educação na Saúde. Política Nacional de Educação Permanente em Saúde [Internet]. Brasília (DF); 2009 [citado 2011 Mai 19]. Available in: http://bvsms.saude.gov.br/bvs/publicacoes/ politica_nacional_educacao_permanente_saude.pdf.

\section{Author's address / Endereço do autor / Dirección del autor}

Amanda de Araújo Romera

Rua Horácio Trajano de Oliveira, 985, Cristo Redentor 58070-450, João Pessoa, PB

E-mail: amanda.romera@hotmail.com
Received: 24.05.2013

Approved: 17.01.2014 